\title{
Anthropogenic influence on SOA and the resulting radiative forcing
}

\author{
C. R. Hoyle ${ }^{1,3}$, G. Myhre ${ }^{2}$, T. K. Berntsen ${ }^{1,2}$, and I. S. A. Isaksen ${ }^{1,2}$ \\ ${ }^{1}$ Department of Geosciences, University of Oslo, Norway \\ ${ }^{2}$ Center for International Climate and Environmental Research, Oslo, Norway \\ ${ }^{3}$ Institute for Atmospheric and Climate Science, ETH Zurich, Zurich, Switzerland
}

Received: 11 September 2008 - Published in Atmos. Chem. Phys. Discuss.: 3 November 2008

Revised: 9 April 2009 - Accepted: 9 April 2009 - Published: 23 April 2009

\begin{abstract}
The effect of chemical changes in the atmosphere since the pre-industrial period on the distributions and burdens of Secondary Organic Aerosol (SOA) has been calculated using the off-line aerosol chemistry transport model Oslo CTM2. The production of SOA was found to have increased from about $35 \mathrm{Tg} \mathrm{yr}^{-1}$ to $53 \mathrm{Tg} \mathrm{yr}^{-1}$ since preindustrial times, leading to an increase in the global annual mean SOA burden from $0.33 \mathrm{Tg}$ to $0.50 \mathrm{Tg}$, or about $51 \%$. The effect of allowing semi-volatile species to partition to sulphate aerosol was also tested, leading to an increase in SOA production from about $43 \mathrm{Tg} \mathrm{yr}^{-1}$ to $69 \mathrm{Tg} \mathrm{yr}^{-1}$ since pre-industrial times, while the annual mean SOA burden increased from $0.44 \mathrm{Tg}$ to $0.70 \mathrm{Tg}$, or about $59 \%$. The increases were greatest over industrialised areas, especially when partitioning to sulphate aerosol was allowed, as well as over regions with high biogenic precursor emissions. The contribution of emissions from different sources to the larger SOA burdens has been calculated. The results suggest that the majority of the increase was caused by emissions of primary organic aerosols (POA), from fossil fuel and bio fuel combustion. As yet, very few radiative forcing estimates of SOA exist, and no such estimates were provided in the latest IPCC report. In this study, we found that the change in SOA burden caused a radiative forcing (defined here as the difference between the pre-industrial and the present day run) of $-0.09 \mathrm{~W} \mathrm{~m}^{-2}$, when SOA was allowed to partition to both organic and sulphate aerosols, and $-0.06 \mathrm{~W} \mathrm{~m}^{-2}$ when only partitioning to organic aerosols was assumed. Therefore, the radiative forcing of SOA was found to be stronger than the best estimate for POA in the latest IPCC assessment.
\end{abstract}

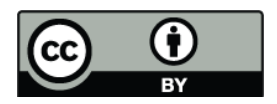

Correspondence to: C. R. Hoyle (c.r.hoyle@geo.uio.no)

\section{Introduction}

Atmospheric aerosols play a key role in determining the Earth's radiation budget (IPCC, 2007; Schulz et al., 2006; Kaufman et al., 2002). Secondary organic aerosol (SOA) represents an important, and under certain circumstances, the major, fraction of the global organic aerosol (OA, i.e. SOA+POA) burden (Kanakidou et al., 2005).

There has been considerable change to the composition and magnitude of emissions from anthropogenic activities since pre-industrial times, therefore it is important to investigate how these changes have influenced the distribution and global burden of organic aerosols.

The change in SOA production and burden since preindustrial times was first examined with a global model by Kanakidou et al. (2000), who considered SOA formation only from the oxidation products of the reaction of $\alpha$ - and $\beta$-pinene with ozone. Subsequent studies involved a range of monoterpenes and other reactive volatile organic compounds (ORVOC), but used prescribed oxidant fields (Chung and Seinfeld, 2002), or did not include SOA formation from the oxidation products of isoprene, or anthropogenic SOA precursors (Liao and Seinfeld, 2005). A recent study by Tsigaridis et al. (2006) used $\alpha$ - and $\beta$-pinene to represent biogenic SOA precursors, and toluene and xylene to represent the anthropogenic SOA precursors, however SOA formation from isoprene oxidation was taken into account using a $0.2 \%$ aerosol molar yield, leading to a far lower contribution of isoprene to present day SOA burdens than that found by Henze and Seinfeld (2006). In the present study we calculated the change in SOA production, burden and radiative forcing since the pre-industrial times, accounting for SOA formation from four classes of monoterpene as well as sesquiterpenes, ORVOC, benzene, toluene, xylene, trimethylbenzene and isoprene. Oxidation of these precursors was calculated with a comprehensive global tropospheric chemistry scheme.

Published by Copernicus Publications on behalf of the European Geosciences Union. 
By performing several model integrations, including emissions from different sources, the contribution of increases in biomass burning POA to the total increase in SOA was separated from the increase due to the anthropogenic influence on gas phase atmospheric chemistry and direct emissions of organic aerosols from fossil and bio fuel burning.

The radiative forcing of the changes in SOA was calculated. The radiative forcing is defined as a change in the net radiative fluxes from a perturbation to the climate system (either from anthropogenic or natural causes) (Forster et al., 2007). Here we use the term radiative forcing for all anthropogenic influences on the SOA abundance. These can either be caused by emissions of anthropogenic SOA precursors, anthropogenically induced change in the oxidants involved in the formation of SOA, or anthropogenic change in the aerosol to which SOA partition. We underscore that all three of these mechanisms to change the SOA burden are of anthropogenic origin and all lead to an anthropogenic change in the SOA concentration. We assume that in the preindustrial experiment the anthropogenic modification of the global aerosol budget was minimal, therefore when we refer to anthropogenic changes here, we mean the difference between present day and pre-industrial values. We classify the whole of the difference in biomass burning emissions between the pre-industrial inventory and the present day inventory as an anthropogenic change.

In Sect. 2, the chemistry transport model (CTM), the SOA scheme and the details of the model experiments are described. The radiative transfer model used to calculate the radiative forcing of the change in SOA burden is described in Sect. 3, and the results are presented in Sect. 4. Section 5 provides a summary and discussion.

\section{The Oslo CTM2}

The Oslo CTM2 is a three-dimensional off-line chemistry transport model, which was run in T42 (approximately $2.8^{\circ} \times 2.8^{\circ}$ ) resolution for this study. The meteorological data used was generated by running the Integrated Forecast System (IFS) of the European Centre for Medium Range Weather Forecasts (ECMWF), for the year 2004, and was updated (off-line) in the CTM every three hours. The same meteorological data was used for both the present day and the pre-industrial simulations. Although the consideration of changes in SOA due to meteorological factors is outside the scope of this study, it must be noted that any systematic differences in precipitation or temperature between the pre-industrial climate and the present would affect the burden or production of SOA through deposition or partitioning processes respectively. The effect of these factors is also discussed in Sect. 4.2. In this study the analysis is restricted to the chemical changes in the atmosphere between the preindustrial times and the present.
The model is divided into 40 layers between the surface and $10 \mathrm{hPa}$. The chemical time step in the troposphere was $15 \mathrm{~min}$, and the transport time step was based on the CFL criteria. In the free troposphere the greatest possible transport time step was one hour and in the boundary layer it was 15 min.

In the configuration used for the present day simulation, the model included 122 gas and condensed phase chemical species, all of which were transported. The chemistry scheme accounted for the most important parts of the ozone$\mathrm{NO}_{\mathrm{x}}$-hydrocarbon chemistry cycle. For the chemistry calculations, the QSSA chemistry solver (Hesstvedt et al., 1978) was used. More detailed descriptions of the model can be found in Berglen et al. (2004) and Berntsen and Isaksen (1997).

The SOA module which has recently been added to the Oslo CTM2 accounts for SOA formation from the oxidation products of biogenically emitted volatile organic compounds (predominantly monoterpenes and isoprene) as well as benzene, toluene, xylene, and other aromatic compounds. Volatile hydrocarbons were emitted in the lowest layer of the model and oxidised in the gas phase by $\mathrm{OH}, \mathrm{O}_{3}$ and $\mathrm{NO}_{3}$, to give semi-volatile oxidation products according to a twoproduct model (Odum et al., 1996). These products were allowed to partition to existing organic aerosol (also to ammonium sulphate aerosol in some experiments) with the reversible partitioning between gas and aerosol phase being calculated using empirically determined partitioning coefficients (these are the same as those in Henze and Seinfeld (2006) and Tsigaridis and Kanakidou (2003) for the oxidation products of isoprene and aromatic species, respectively, while the coefficients for the remaining species come from Chung and Seinfeld (2002)). A $\mathrm{NO}_{\mathrm{x}}$ (or $[\mathrm{NO}] /\left[\mathrm{HO}_{2}\right]$ ) dependence of the volatility of the organic oxidation products as described by Henze et al. (2008) is not accounted for. A single enthalpy of vaporisation, $\Delta \mathrm{H}$, of $42 \mathrm{~kJ} \mathrm{~mol}^{-1}$ has been used for all SOA species, as in previous studies (e.g., Chung and Seinfeld, 2002; Heald et al., 2008; Henze et al., 2008). The gas and aerosol phase oxidation products as well as the precursor VOC were subject to wet deposition in both convective and large scale rain, whereby $80 \%$ of the aerosol phase semi-volatile organic species were assumed to dissolve into avaliable cloud water (Chung and Seinfeld, 2002), and the solubilities of the gas phase species were calculated according to their Henry's Law coefficients as described in (Hoyle et al., 2007). Additionally, the aerosol phase species in the lowest model layer had a dry deposition loss term applied. A full description, as well as a validation of the SOA scheme against surface measurements is given in Hoyle et al. (2007).

The sulphate aerosol to which the SOA partitions in several of the modelling experiments described here should be considered as an ammonium sulphate like aerosol (hereafter ASLA). Ammonium sulphate aerosol is often used as a seed aerosol in chamber experiments (e.g., Kleindienst et al., 
Table 1. The model experiments which were carried out. The year used for the biomass burning emissions of POA and sulphur is given in the column "BB year". The year used for all other emissions is given in the column "Emis. year". The entries in the column "Sulph." indicate whether or not SOA was allowed to partition to ASLA.

\begin{tabular}{lccc}
\hline Name & Emis. year & BB year & Sulph. \\
\hline Pind_nosul & 1750 & 1750 & NO \\
Pres_nosul & 2004 & 2004 & NO \\
Pind_sul & 1750 & 1750 & YES \\
Pres_sul & 2004 & 2004 & YES \\
Pres_BBpind & 2004 & 1750 & YES \\
Pind_BBpres & 1750 & 2004 & YES \\
\hline
\end{tabular}

1999; Meyer et al., 2009). Although both ammonium and sulphate are very common aerosol components in the troposphere, there are few areas where neutralised ammonium sulphate has been observed. Rather, measurements and modelling studies indicate that the ammonium and sulphate containing aerosol is, for the most part, acidic (Dibb et al., 1996; Huebert et al., 1998; Martin et al., 2004; Kline et al., 2004). There are studies showing evidence for the uptake of organic species into acidic sulphate aerosols (e.g., Iraci and Tolbert, 1997; Jang et al., 2002; Kleindienst et al., 2006), and even the irreversible partitioning of organics to these aerosols, because of esterification reactions (Surratt et al., 2007; Lukács et al., 2009). In this study, therefore, modelled sulphate aerosol is used as a proxy for ASLA. While this is a parameterisation that should be improved in the future, it would be incorrect to completely disregard this partitioning. However, a limitation of the parameterisation used here is that the ASLA is included in the mass for the absorptive partitioning calculation. Irreversible partitioning, as described by (Surratt et al., 2007) and (Lukács et al., 2009), is therefore not accurately represented. This is a matter that we aim to improve in the future, as more information on the processes and reaction rates involved becomes available.

Model runs with and without SOA partitioning to ASLA were considered in Hoyle et al. (2007), for the present day, and it was found that allowing partitioning to ASLA improved the comparison with measurements substantially. In the present work, SOA production, burden and radiative forcing is discussed, again from model runs with and without partitioning to ASLA, in order to investigate the sensitivity of the SOA burden to an uptake on sulphate aerosol.

\subsection{Experiments}

Six model experiments were carried out to investigate the change in SOA production and burden since pre-industrial times, as listed in Table 1. The first two experiments (Pind_nosul and Pres_nosul) were run for the years 1750 and 2004 , respectively. In these experiments the primary organic aerosol, which was available for the SOA to partition to, was emitted via fossil fuel, bio fuel and biomass combustion. The next two experiments (Pres_sul and Pind_sul) were the same as the first two, however partitioning of semi-volatile species to ASLA was allowed.

Run Pres_BBpind was identical to Pres_sul except that POA and sulphur emissions from biomass burning were set to 1750 s levels. Similarly, Pind_BBpres was a run with 1750 s emissions, except for biomass burning emissions of POA and sulphur, which were set to 2004 levels. It is important to note that in the latter two runs, the only components of biomass burning which were changed were the $\mathrm{POA}$ and $\mathrm{SO}_{2} / \mathrm{SO}_{4}$ emissions, the other biomass burning components were as for the base year (2004 and 1750, respectively). The runs were designed in this way to permit extraction of the effect of increasing aerosol available for partitioning, due to increases in biomass burning as a result of anthropogenic activity.

For all model runs, the meteorological data for 2004 was used. The emissions used in the present day and preindustrial runs are described in Sect. 2.2. Using the last four model runs, it is possible to examine the changes in SOA production and burden since pre-industrial times, as well as to separate the contributions of increases in POA and ASLA from biomass burning from those of fuel burning or industrial emissions to the SOA burden. Runs Pres_nosul and Pind_nosul help characterise the effects of increases in ASLA since pre-industrial times.

\subsection{Emissions}

The biogenic emissions used for the present day and the preindustrial runs were identical, as changes since pre-industrial times are expected to be only 2-3\% (Lathière et al., 2005). Keeping the biogenic emissions constant had the added advantage of facilitating the calculation of the change in SOA directly related to anthropogenic emissions changes. Biogenic emissions of monoterpenes, isoprene and ORVOC were taken from the Global Emissions Inventory Activity (GEIA) data base and are representative of 1990 (Guenther et al., 1995). Isoprene emissions were reduced so that the annual global emissions were $220 \mathrm{Tg} \mathrm{yr}^{-1}$ (IPCC, 2001). This is lower than recent estimates of isoprene emissions (460$570 \mathrm{Tg} \mathrm{yr}^{-1}$ (Lathière et al., 2006), 500-750 $\mathrm{Tg} \mathrm{yr}^{-1}$ (Guenther et al., 2006) and 374-449 $\mathrm{Tg} \mathrm{yr}^{-1}$ Muller et al., 2008), therefore the amount of SOA formed from oxidation products of isoprene may be underestimated. Since isoprene emission estimates larger than those given in IPCC (2001) have appeared, there has been a discrepancy between these estimates and the magnitude of isoprene emissions suggested by global model studies. Increasing the isoprene emissions in global models has the effect of depleting $\mathrm{OH}$ concentrations, and this depletion could only be balanced by far too large $\mathrm{O}_{3}$ concentrations. Recent work by Lelieveld et al. (2008) however, has suggested a mechanism by which $\mathrm{OH}$ consumed 
Table 2. The emissions used in the model runs. BVOC includes the total emissions of biogenic volatile organic carbon, which can react to form SOA. AVOC is the anthropogenic equivalent. The very minor amounts of aromatic species in the pre-industrial runs are related to biomass burning emissions. References for the emission data sets are provided in the text.

\begin{tabular}{lcccccc}
\hline Model run & \multicolumn{7}{c}{ Emissions } \\
\hline & $\mathrm{CO}$ & $\mathrm{NO}_{\mathrm{x}}$ & $\mathrm{POA}$ & $\mathrm{BVOC}$ & AVOC & Isoprene \\
\hline Pind_sul & $343 \mathrm{Tg} \mathrm{yr}^{-1}$ & $11.4 \mathrm{Tg}(\mathrm{N}) \mathrm{yr}^{-1}$ & $10.26 \mathrm{Tg}(\mathrm{C}) \mathrm{yr}^{-1}$ & $386 \mathrm{Tg}(\mathrm{C}) \mathrm{yr}^{-1}$ & $1.21 \mathrm{Tg} \mathrm{yr}^{-1}$ & $220 \mathrm{Tg} \mathrm{yr}$ \\
Pres_sul & $1061 \mathrm{Tg} \mathrm{yr}^{-1}$ & $46.7 \mathrm{Tg}(\mathrm{N}) \mathrm{yr}^{-1}$ & $30.40 \mathrm{Tg}(\mathrm{C}) \mathrm{yr}^{-1}$ & $386 \mathrm{Tg}(\mathrm{C}) \mathrm{yr}^{-1}$ & $21.62 \mathrm{Tg} \mathrm{yr}^{-1}$ & $220 \mathrm{Tg} \mathrm{yr}$ \\
Pres_BBpind & $1061 \mathrm{Tg} \mathrm{yr}^{-1}$ & $46.7 \mathrm{Tg}(\mathrm{N}) \mathrm{yr}^{-1}$ & $18.04 \mathrm{Tg}(\mathrm{C}) \mathrm{yr}^{-1}$ & $386 \mathrm{Tg}(\mathrm{C}) \mathrm{yr}^{-1}$ & $21.62 \mathrm{Tg} \mathrm{yr}^{-1}$ & $220 \mathrm{Tg} \mathrm{yr}$ \\
Pind_BBpres & $343 \mathrm{Tg} \mathrm{yr}^{-1}$ & $11.4 \mathrm{Tg}(\mathrm{N}) \mathrm{yr}^{-1}$ & $22.62 \mathrm{Tg}(\mathrm{C}) \mathrm{yr}^{-1}$ & $386 \mathrm{Tg}(\mathrm{C}) \mathrm{yr}^{-1}$ & $1.21 \mathrm{Tg} \mathrm{yr}^{-1}$ & $220 \mathrm{Tg} \mathrm{yr}$ \\
Pind_nosul & $343 \mathrm{Tg} \mathrm{yr}^{-1}$ & $11.4 \mathrm{Tg}(\mathrm{N}) \mathrm{yr}^{-1}$ & $10.26 \mathrm{Tg}(\mathrm{C}) \mathrm{yr}^{-1}$ & $386 \mathrm{Tg}(\mathrm{C}) \mathrm{yr}^{-1}$ & $1.21 \mathrm{Tg} \mathrm{yr}^{-1}$ & $220 \mathrm{Tg} \mathrm{yr}$ \\
Pres_nosul & $1061 \mathrm{Tg} \mathrm{yr}^{-1}$ & $46.7 \mathrm{Tg}(\mathrm{N}) \mathrm{yr}^{-1}$ & $30.40 \mathrm{Tg}(\mathrm{C}) \mathrm{yr}^{-1}$ & $386 \mathrm{Tg}(\mathrm{C}) \mathrm{yr}^{-1}$ & $21.62 \mathrm{Tg} \mathrm{yr}^{-1}$ & $220 \mathrm{Tg} \mathrm{yr}$ \\
\hline
\end{tabular}

in isoprene oxidation may be recycled, which, if confirmed, would permit larger isoprene emissions in global models.

For the present day simulation, emissions of $\mathrm{CO}, \mathrm{NO}_{\mathrm{x}}$ and non-methane hydrocarbons were taken from the Precursors of Ozone and their Effects in the Troposphere (POET) inventory (Granier et al., 2005). Methane mixing ratios were fixed at $1750 \mathrm{ppbv}$ at the surface for the present day simulations. Emissions of POA from biomass burning were taken from the Global Fire Emissions Database version 2 (GFEDv2), for 2004 (van der Werf et al., 2006), and POA emissions from fossil fuel and bio fuel combustion were from the inventory of Bond et al. (2004).

The pre-industrial emissions of POA from biomass burning and from bio fuel burning were from the AeroCom (Aerosol Inter-Comparison project) emissions datasets (Dentener et al., 2006). In the pre-industrial experiments, all fossil fuel related and industrial emissions were set to zero, and annual emissions of non-POA species emitted via biomass burning (for example $\mathrm{SO}_{2}, \mathrm{CO}, \mathrm{NO}_{\mathrm{x}}$ and $\mathrm{NMHC}$ ) were scaled down. This scaling was achieved by dividing the POA emissions for 1750 by the average POA emissions for 2000-2004, in order to generate monthly mean scaling factors for each point on the model grid at the surface. The resulting annual and global mean reduction in each type of emissions in the pre-industrial runs was $65 \%$. This method implicitly assumes that biomass burning emissions of all the scaled species are proportional to changes in emissions of POA, however, given the large uncertainty in pre-industrial biomass burning emissions, this approach is justified. Methane mixing ratios at the surface were fixed at $700 \mathrm{ppb}$. The emissions used in each of the model experiments are summarised in Table 2.

\section{The radiative transfer model}

The radiative forcing of the SOA was calculated using a radiative transfer model. A short wave multi-stream model, using the discrete-ordinate method of Stamnes et al. (1988) is adopted. The radiative transfer model includes the radiative effects of aerosols, clouds, Rayleigh scattering, and absorp- tion by gases. The calculations were performed at T42 horizontal resolution and in 40 vertical layers between the surface and $10 \mathrm{hPa}$. Meteorological data including cloud cover was the same as that used to drive the CTM. Aerosols had no influence on cloud formation in this study and as the radiative transfer calculation was performed off-line, there was no feed-back effect on the model meteorology. Aerosol optical properties of SOA were taken to be similar to POA (Myhre et al., 2007), and the aerosol was assumed to be externally mixed.

For SOA, we assumed a lognormal size distribution with geometric mean radii of $0.05 \mu \mathrm{m}$ and a standard deviation of 2.0. The adopted refractive index for SOA was (1.529, $-1.0 \mathrm{e}-7 \mathrm{i})$ at $550 \mathrm{~nm}$. Hygroscopic growth of hydrophilic SOA was taken into account (Peng et al., 2001). The assumption of external mixture of SOA needs to be considered, since we assumed SOA partitioning to ASLA, and mixture with organic material will reduce the hygroscopic growth of inorganic compounds (Brooks et al., 2004; Prenni et al., 2003; Svenningsson et al., 2006). However, measurements show that the water uptake of mixed inorganic/organic particles is mostly similar to the combination of the water uptake of unmixed organic and inorganic material (Brooks et al., 2004; Prenni et al., 2003; Svenningsson et al., 2006), indicating that assumption of external mixture is reasonable. However, further investigations and understanding of the hygroscopic growth of organic and inorganic mixtures would be important to confirm this.

The radiative forcing calculations were performed as the difference in the irradiance at the top of the atmosphere between simulations for pre-industrial and present day model runs. A more detailed description of the radiative transfer model can be found in Myhre et al. (2002).

\section{Results}

\subsection{The change in SOA production and burden}

The annual global production and mean burden of SOA for the model runs is shown in Table 3. The increase in annual global mean SOA burden since the pre-industrial period was 
Table 3. The global, annual mean SOA production and burden for the various model runs.

\begin{tabular}{lcc}
\hline Run & Production $\left(\mathrm{Tg} \mathrm{yr}^{-1}\right)$ & Burden $(\mathrm{Tg})$ \\
\hline Pind_sul & 42.8 & 0.44 \\
Pind_nosul & 34.5 & 0.33 \\
Pres_sul & 68.8 & 0.70 \\
Pres_nosul & 53.4 & 0.50 \\
Pind_BBpres & 47.0 & 0.51 \\
Pres_BBpind & 62.4 & 0.59 \\
\hline
\end{tabular}

$0.17 \mathrm{Tg}$, or about $52 \%$, while the increase in production was found to be $18.9 \mathrm{Tg}(54.8 \%)$.

When partitioning to ASLA was allowed, the increase in annual mean SOA burden between the pre-industrial run Pind_sul and the present day run Pres_sul was larger, at 59\% $(0.26 \mathrm{Tg})$. When all the emissions except POA and sulphur from biomass burning were held at pre-industrial levels (Pind_BBpres), an increase in the mean SOA burden of $16 \%(0.07 \mathrm{Tg})$ was calculated relative to Pind_sul, and when the 1750 biomass burning emissions of POA and sulphur were used in the present day run (Pres_BBpind), an increase in the SOA burden of $34 \%$, or $0.15 \mathrm{Tg}$, relative to Pind_sul, was found. This indicates that up to $58 \%$ of the total pre-industrial to present day SOA increase was due to anthropogenic emissions from fossil fuel and bio fuel burning, and $27 \%$ was due to increases in POA and ASLA from biomass burning. The remaining 15\% increase found between Pind_sul and Pres_sul can be explained by differences in the oxidant fields due to biomass burning emissions of $\mathrm{NO}_{\mathrm{x}}$ and VOC, by differences in the co-location of SOA forming species and POA or ASLA available for partitioning, and by the fact that the fraction of semi-volatile species partitioning to the aerosol phase is not linearly dependent on the aerosol mass.

The contribution of anthropogenic SOA precursor emissions to the present day SOA burden could not be calculated exactly due to the contribution of several emission sources (including biomass burning) to the SOA forming species. However, as the total emissions of the biogenic SOA precursors are many times greater than the anthropogenic SOA precursor emissions (see Table 2), it is clear that only a very minor fraction of the modelled increase in SOA is due to anthropogenic SOA precursors.

The fact that emissions from fossil and bio fuel burning contribute around twice as much to the SOA increase as the biomass burning emissions can be explained by examining the increase in POA resulting from these processes. The change in POA emissions between 1750 and 2004 was greatest for emissions from fossil and bio fuels, (an increase of $12.54 \mathrm{Tg} \mathrm{yr}^{-1}$ ), while emissions from biomass burning increased by $8.7 \mathrm{Tg} \mathrm{yr}^{-1}$. As shown below, the most widespread increases in SOA have occurred over industri- alised areas, where the increase in abundance of pre-existing aerosol, upon which the SOA can partition, has been the greatest.

The distribution of the changes in SOA at the surface, and in the total column are shown in Fig. 1. In panel A, showing the difference between runs Pres_nosul and Pind_nosul, substantial increases can be seen both in the biomass burning regions of South America and southern Africa. Large increases are also obvious in South East Asia, and there are increases over the industrialised areas, such as Europe and the east coast of the USA. In the column values (panel E), the increase in SOA over the ocean, in the outflow from the USA, Africa and South America can be seen. The red line indicates the zero contour. In some of the more remote areas there have been very small decreases in SOA burden, most obviously in the column values at high southern latitudes. The decreases at the surface, over land, are a result of lower biomass burning POA emissions in the present day inventory than in the pre-industrial inventory (this is more clearly shown in panels D and H). Additionally, if an area of high emissions shifts slightly in location between the preindustrial and present day data sets, this can also lead to an apparent decrease in emissions in that region. The decreases in the column values on the other hand, were due to changes in anthropogenic emissions affecting the oxidation and partitioning of SOA species, causing them to be removed closer to the sources, as discussed below. In panels B and $\mathrm{F}$, showing the increase in SOA when partitioning to ASLA was allowed (Pres_sul-Pind_sul), the increases in SOA are higher than in panels A and E, especially over industrialised areas. Particularly notable is the larger increase in the column SOA values to the east of Europe and also on the east coast of North America. Panels $\mathrm{C}$ and $\mathrm{G}$ show the difference between runs Pind_sul and Pres_BBpind. Most of the increased SOA over the east coast of the USA, South East Asia and, in the total column, to the east of Europe, is reproduced here. Here also, the decreases in SOA observed in the more remote regions were due to the increased removal of SOA close to the sources. Panels D and H show the SOA change when 2004 biomass burning emissions of POA and sulphur were included in the pre-industrial run (the difference between Pind_sul and Pind_BBpres). This shows that most of the increase in SOA over Indonesia, as well as over Africa and South America, which was seen in panels B and F, was due to larger biomass burning emissions. Again, here it is evident that the decreases in SOA observed over some land areas are due to reductions in POA from biomass burning. The increased fraction of semi-volatile species in the aerosol phase, due to the additional ASLA and POA from biomass burning, lead to lower SOA values in areas far from the biomass burning, due to the increased wet removal of SOA close to the sources.

Note that despite the small decreases in SOA burden at high southern latitudes in panels $\mathrm{C}$ and $\mathrm{D}$, panel B shows that there was still a net increase in the SOA burden in this area. 


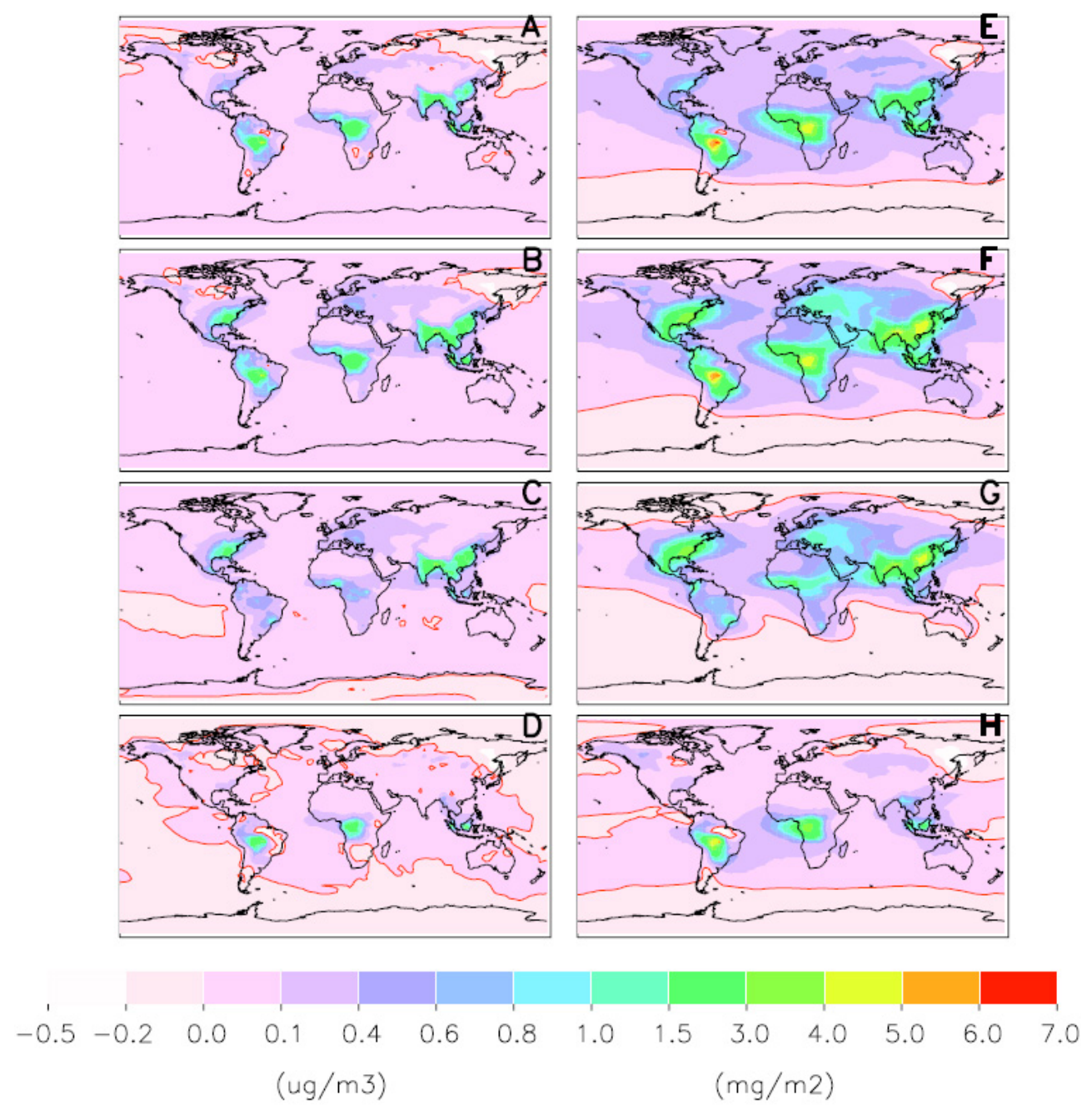

Fig. 1. The change in annual mean SOA concentration since pre-industrial times. Panels (A-D) show changes at the surface, panels (E-H) show changes for the total column amount of SOA. The zero contour is indicated in red. Panels (A) and (E) show the difference between runs Pres_nosul and Pind_nosul, panels (B) and (F) show the difference between runs Pres_sul and Pind_sul, panels (C) and (G) show the difference between runs Pres_BBpind and Pind_sul, and panels (D) and (H) show the difference between runs Pind_BBpres and Pind_sul.

Since the mass of semi-volatile species in the aerosol phase affects the partitioning, once more semi-volatile species partition to the aerosol phase, the mass available for partitioning increases, and even more of the species partition to the aerosol phase. Therefore the SOA burden depends nonlinearly on the available aerosol mass. The combined increase in OA and ASLA due to present day industrial emissions and biomass burning lead to the increase in SOA shown in panel B.

The increase in SOA did not occur uniformly throughout the atmospheric column, rather the largest increases were seen at the surface. Figure 2 shows the annual, zonal mean change in SOA concentration for the different model runs. Panel A shows the difference between Pres_nosul and Pind_nosul. Between these two runs, the largest increases in SOA were in the tropics and close to the surface, be- low $600 \mathrm{hPa}$. Increases higher in the atmosphere can also be seen, especially in the Northern Hemisphere, where significant SOA increases were found even at polar latitudes. At high southern latitudes, the increase was very small, due to the lack of sources. Transport from lower latitudes at altitudes around $300 \mathrm{hPa}$ appears less active than in the Northern Hemisphere. SOA increased slightly between the two runs in the lower troposphere at high northern latitudes.

Around the tropopause however, the abundance of SOA actually decreased in Pres_nosul compared to Pind_nosul. Additionally, the gas phase species which partition to form SOA were reduced in the upper troposphere in Pres_nosul compared to Pind_nosul (not shown). Compared to the preindustrial atmosphere, with present day industrial emissions concentrations of the oxidants $\mathrm{O}_{3}$ and $\mathrm{NO}_{3}$ are higher, while $\mathrm{OH}$ is lower in the global average, but higher near sources 


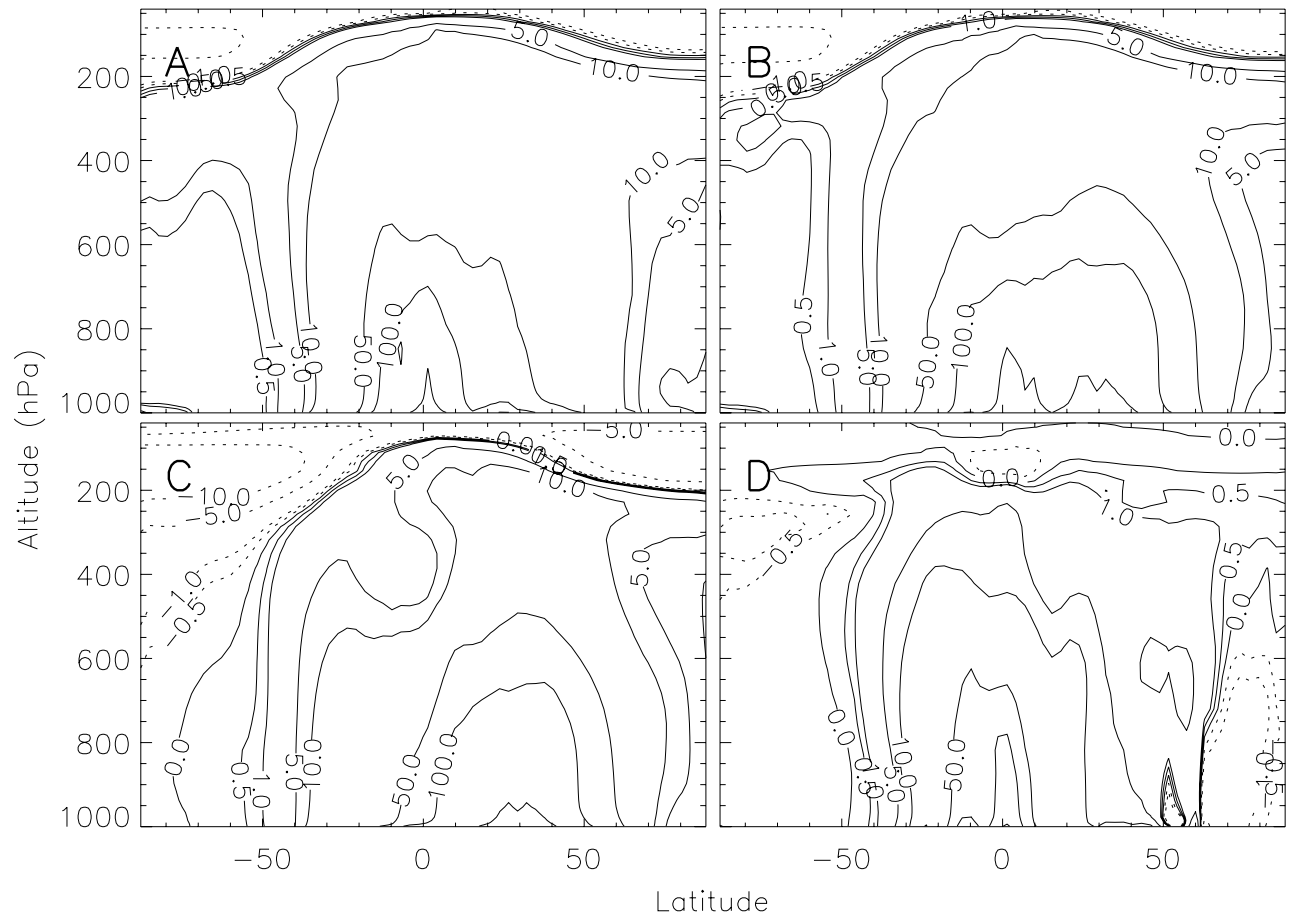

Fig. 2. The annual, zonal mean increase in SOA between the pre-industrial model runs and the present day runs (ng $\left.\mathrm{m}^{-3}\right) . \mathrm{Panel}(\mathbf{A})$ shows the difference between Pres_nosul and Pind_nosul, panel (B) shows the difference between Pres_sul and Pind_sul. Panel (C) shows the difference between Pres_BBpind and Pind_sul, and panel (D) the difference between Pind_BBpres and Pind_sul. The highest isoline in panels (A) (B) and (C) is $200 \mathrm{ng} \mathrm{m}^{-3}$.

of anthropogenic emissions, which are often near sources of SOA precursors. This resulted in a shift in SOA precursor oxidation towards the surface. As the SOA precursors are less soluble than the oxidation products, greater oxidation near the surface lead to higher SOA concentrations near the surface, but lower SOA concentrations higher in the atmosphere, as the species are washed out. In the pre-industrial atmosphere, more of the SOA precursors were transported further up in the troposphere before they were oxidised. The actual SOA concentrations near the tropical tropopause are around a factor of 10-50 less than at the surface.

Changes in partitioning due to higher POA masses in the present day atmosphere also affect the distribution of SOA.

Panel B shows the difference between Pres_sul and Pind_sul. Here the situation is similar to panel A, with the largest SOA increase occurring in the tropics near the surface. However, there is more of an increase in SOA at the surface in the northern sub-tropics in panel B, due to the effect of partitioning to ASLA near industrialised areas. The increase in SOA throughout the troposphere at northern mid-latitudes is also greater in panel B than panel A. In panel A, there is a slightly larger SOA concentration around $200 \mathrm{hPa}-400 \mathrm{hPa}$ than in panel $\mathrm{B}$, as the increased partitioning to ASLA in the Pres_sul run lead to greater wet removal of SOA closer to the source than in Pres_nosul.
In panel $\mathrm{C}$, the increase in SOA due to industrial and fuel burning emissions is shown (the difference between run Pres_BBpind and Pind_sul). This panel shows clearly that the peak in SOA values between $20^{\circ} \mathrm{N}$ and $40^{\circ} \mathrm{N}$ is a result of industrial activity. Further, most of the increase throughout the northern mid-latitude troposphere is reproduced in panel C. The increase in SOA extends further south than in panel $\mathrm{D}$, due to the more widespread emissions.

Panel D shows the increase in SOA between Pind_sul and Pind_BBpres. The reduction in SOA at high northern latitudes was due to the lower biomass burning emissions in the 2004 inventory (see also Fig. 1). Most of the tropical increases, both at the surface and higher in the troposphere are accounted for in this panel, and therefore result from increased biomass burning emissions of POA and sulphur.

The total increase in the high southern latitudes, seen in panel B, was a result of higher partitioning of semivolatile species into the aerosol phase, when the biomass as well as fuel burning POA sources were included. As described above, the partitioning of semi-volatile species is non-linearly dependent on the aerosol mass, therefore the changes seen in panel B are not the simple sum of the changes in panels $\mathrm{C}$ and $\mathrm{D}$. Interestingly, most of the upper tropospheric SOA increase over the tropics appears to have been a result of industrial or fuel burning emissions. 
The 51\%-59\% increase in the global annual mean SOA burden since pre-industrial times is significantly larger than values calculated in other recent studies, for example $25 \%$ (Tsigaridis et al., 2006) and 43\% (Liao and Seinfeld, 2005), however, it is much lower than the estimates from earlier studies, for example 300\% (Kanakidou et al., 2000) and $316 \%$ (Chung and Seinfeld, 2002). A SOA scheme similar to that of Liao and Seinfeld (2005) was used here, however, we found a much greater increase of the SOA burden relative to the POA burden.

$\mathrm{SOA}, \mathrm{POA}$ and $\mathrm{SO}_{4}$ production and burden from other studies are compared with the values calculated here, in Table 4. In Liao and Seinfeld (2005), the $43 \%$ increase in SOA was accompanied by an increase in POA by a factor of 13.2, in contrast, when only partitioning to organic aerosol was accounted for in the Oslo CTM2, SOA increased by $63 \%$, as POA increased by a factor of about 2.8. Reasons for the different SOA burdens, or changes in burdens between different models are discussed in more detail in Sect. 4.2, however the larger increase in SOA seen in the present work compared to Liao and Seinfeld (2005) is probably due to the different resolutions and transport characteristics of the two models. The GISS GCM II' as it was used in Liao and Seinfeld (2005) had a resolution of 4 degrees in latitude, 5 degrees in longitude and 9 layers from the surface to $10 \mathrm{hPa}$. Further, it has been shown that the GISS GCM II' has a more rapid transport from emission regions than the Oslo CTM2 (Schulz et al., 2006). The partitioning of semi-volatile species depends on the concentration of the species in the gas phase and the amount of mass available for partitioning. A higher concentration can be maintained with a higher model resolution. On the other hand, a coarser model grid will lead to faster diffusion of POA from the source areas, a lower concentration, and less partitioning of semi-volatile organic species to the aerosol phase.

The fractional increase in sulphate since pre-industrial times, in Tsigaridis et al. (2006), is slightly higher than in this work (a factor of $2.6 \mathrm{vs}$. the factor of 2.1 increase in this work), while the increase in POA is slightly lower (a factor of 2.2 vs. the factor 2.7 increase here). However, the absolute increase in POA between Pind_sul and Pres_sul was about $0.8 \mathrm{Tg}$, and the absolute increase in SOA was $0.26 \mathrm{Tg}$, while Tsigaridis et al. (2006) found a total increase in POA of $0.33 \mathrm{Tg}$ and an increase in SOA of $0.16 \mathrm{Tg}$. Therefore, the increase in SOA is higher in Tsigaridis et al. (2006) on a per-terragram of POA basis. The total changes in organic aerosol, between pre-industrial times and the present, are $1.27 \mathrm{Tg}, 0.49 \mathrm{Tg}, 1.22 \mathrm{Tg}$ and $1.16 \mathrm{Tg}$ in Liao and Seinfeld (2005), Tsigaridis et al. (2006), Chung and Seinfeld (2002) and Pres_sul-Pind_sul respectively, thus the total change in organic aerosol in this study is similar to that in other works. Interestingly, Tsigaridis et al. (2006) predicted SOA values to be larger than POA, both in pre-industrial times and present, while Liao and Seinfeld (2005) found SOA burdens to be significantly larger than POA in pre-industrial times, and signif- icantly lower than POA burdens in the present. In this work, and that of Chung and Seinfeld (2002), the global mean SOA burden is lower than the POA burden, both in pre-industrial times and the present.

\subsection{Comparison of SOA production and burden with other recent modelling studies}

The SOA production and burden from the present work is compared with some other recent modelling studies in Table 5. The burden of SOA calculated here is similar to that found in other studies, despite the production being higher. In the case of isoprene, the production is similar, despite the emissions being slightly less than half that of the other models. Without carrying out a detailed model inter-comparison (which we believe would be a very valuable exercise), it is difficult to isolate the exact reasons for these differences. The discussion below is not exhaustive, but highlights a few key factors which may have a substantial effect on production and burden of SOA in global models. Further explanation of possible reasons for the difference in SOA production estimates between different modelling studies is given in Hoyle et al. (2007).

Firstly, the SOA production depends upon the ambient temperature through both chemical reaction rates and the temperature dependence of the partitioning coefficient. It was found by Tsigaridis and Kanakidou (2007) that when they increased the boundary layer temperatures used in the partitioning calculation in their model by $2^{\circ} \mathrm{C}$, and the temperatures in the free troposphere by $1^{\circ} \mathrm{C}$, the SOA production was reduced by $11 \%$. A further $10 \%$ reduction was found if the temperature changes were also allowed to affect the chemistry.

In addition, the distributions of SOA precursors, and also the gas phase semi-volatile species which partition to form SOA are subject to wet and dry deposition. Parameterisations for these processes differ between different models, as do the location of precipitation events and the water fluxes. There are large differences between chemistry transport models in the wet deposition of soluble species (Hoyle et al., 2009). Variations in deposition fluxes can cause large differences in SOA burdens even within the same model; for example Tsigaridis et al. (2005) found that inter-annual variations in wet and dry deposition caused changes of around $14.5 \%$ in the calculated SOA burden.

Differences in model resolution, transport schemes and three dimensional wind fields also lead to different rates of dispersion of precursors and semi-volatile species, and as the partitioning of SOA is dependent upon the concentration of the semi-volatile species, this will affect the production of SOA. The model resolution used in this study is greater than that of Tsigaridis and Kanakidou (2007), and while the horizontal resolution is less than for Heald et al. (2008) and Henze et al. (2008), the vertical resolution is greater. We use ECMWF meteorological fields for 2004 here, however 
Table 4. A comparison between aerosol burdens in this, and similar studies. Values are given for pre-industrial model runs, present day model runs and the fraction change between the two. The units are Tg.

\begin{tabular}{lcccc}
\hline Model study & Species & Pre-ind. & Pres. & Fraction change \\
\hline Liao and Seinfeld (2005) & $\mathrm{SO}_{4}$ & 0.32 & 1.4 & 4.38 \\
& $\mathrm{POA}$ & 0.10 & 1.27 & 13.2 \\
& $\mathrm{SOA}$ & 0.23 & 0.33 & 1.43 \\
Tsigaridis et al. (2006) & $\mathrm{SO}_{4}$ & 0.4 & 1.05 & 2.6 \\
& $\mathrm{POA}$ & 0.27 & 0.6 & 2.2 \\
& $\mathrm{SOA}$ & 0.64 & 0.8 & 1.25 \\
This work (sul) & $\mathrm{SO}_{4}$ & 0.84 & 1.80 & 2.14 \\
& $\mathrm{POA}$ & 0.51 & 1.41 & 2.78 \\
& $\mathrm{SOA}$ & 0.44 & 0.7 & 1.59 \\
This work (nosul) & $\mathrm{POA}$ & 0.51 & 1.41 & 2.78 \\
& $\mathrm{SOA}$ & 0.32 & 0.50 & 1.56 \\
Chung and Seinfeld (2002) & $\mathrm{POA}$ & 0.11 & 1.2 & 10.91 \\
& $\mathrm{SOA}$ & 0.06 & 0.19 & 3.17 \\
\hline
\end{tabular}

Table 5. A comparison of SOA production and burden for the present day, without partitioning to ASLA, with other recent studies. The production from isoprene as well as the isoprene emissions are also included for comparison. Note that all values for Heald et al. (2008) are based on mass of carbon.

\begin{tabular}{lcccc}
\hline Source & $\begin{array}{c}\text { SOA } \\
\text { production }\end{array}$ & $\begin{array}{c}\text { SOA } \\
\text { burden }\end{array}$ & $\begin{array}{c}\text { Isoprene } \\
\text { emissions }\end{array}$ & $\begin{array}{c}\text { SOA from } \\
\text { isoprene }\end{array}$ \\
\hline Tsigaridis and Kanakidou (2007) & $18.6 \mathrm{Tg} \mathrm{yr}^{-1}$ & $0.82 \mathrm{Tg}$ & $467 \mathrm{TgC} \mathrm{yr}^{-1}$ & $4.6 \mathrm{Tg} \mathrm{yr}^{-1}$ \\
Heald et al. (2008) & $24.3 \mathrm{TgC} \mathrm{yr}^{-1}$ & $0.59 \mathrm{Tg}$ & $496 \mathrm{TgC} \mathrm{yr}^{-1}$ & $19.2 \mathrm{TgC} \mathrm{yr}^{-1}$ \\
Henze et al. (2008) & $30.3 \mathrm{Tg} \mathrm{yr}$ & $0.81 \mathrm{Tg}$ & $408 \mathrm{TgC} \mathrm{yr}^{-1}$ & $14.4 \mathrm{Tg} \mathrm{yr}$ \\
This work & $53.4 \mathrm{Tg} \mathrm{yr}$ & $0.5 \mathrm{Tg}$ & $194 \mathrm{TgC} \mathrm{yr}^{-1}$ & $14.0 \mathrm{Tg} \mathrm{yr}$ \\
\hline
\end{tabular}

Tsigaridis and Kanakidou (2007) use ECMWF ERA-15 data for 1990 for their present day run, Henze et al. (2008) use GEOS-4 meteorological data for 2004 and Heald et al. (2008) use the CAM3 atmospheric general circulation model, which generates its own meteorological data. Considering the effect on SOA of the factors described above, it is clear than even if different models were to use the same chemical schemes and emissions they would have different SOA productions and burdens depending on meteorological data and removal schemes.

There are however, also differences in the emissions between the models shown in Table 5. In the present work, biogenic VOC (BVOC) emissions of $386 \mathrm{Tg}(\mathrm{C}) \mathrm{yr}^{-1}$, excluding isoprene, are used (Guenther et al., 1995; Griffin et al., 1999), while Heald et al. (2008) include only $43 \mathrm{Tg}(\mathrm{C}) \mathrm{yr}^{-1}$ of monoterpene emissions. They do not include short lived species such as sesquiterpenes, which are accounted for here. Emissions of $103 \mathrm{Tg}(\mathrm{C}) \mathrm{yr}^{-1}$ of monoterpenes were used by Henze et al. (2008), and Tsigaridis and Kanakidou (2007) included $217.4 \mathrm{Tg} \mathrm{yr}^{-1}$ of non isoprene BVOC which could contribute to SOA production.

With respect to the relation between isoprene production and burden, in addition to the effects described above, de- pending on the $\mathrm{OH}$ chemistry in the models, the efficiency of SOA production from isoprene may drop substantially with increased isoprene emissions. As noted earlier, high isoprene emissions in models have the effect of decreasing the $\mathrm{OH}$ concentration, unless some sort of recycling of $\mathrm{OH}$ is included (Lelieveld et al., 2008). Isoprene is oxidised by both $\mathrm{O}_{3}$ and $\mathrm{OH}$, however, except in the case of Tsigaridis and Kanakidou (2007), only oxidation by $\mathrm{OH}$ leads to SOA formation in the models discussed here. As the isoprene reduces the $\mathrm{OH}$ concentration, the remaining isoprene either reacts with ozone or it is transported further from the source region before being oxidised, and thus has more chance to be removed in precipitation. It was noted in Heald et al. (2008) that SOA formed from isoprene oxidation is enhanced in the upper troposphere with respect to that from monoterpenes, and that it has a lifetime of around 9 days rather than the 7 days for monoterpene SOA (i.e. around 29\% longer). They attribute this to incomplete oxidation of isoprene near the source, and subsequent transport to higher altitudes, where there is less precipitation, similarly to Henze and Seinfeld (2006). The lifetime of SOA from isoprene oxidation in the Oslo CTM2 is 3.7 days, about $9 \%$ longer than the 3.4 days for the remaining SOA species, which may indicate that the 

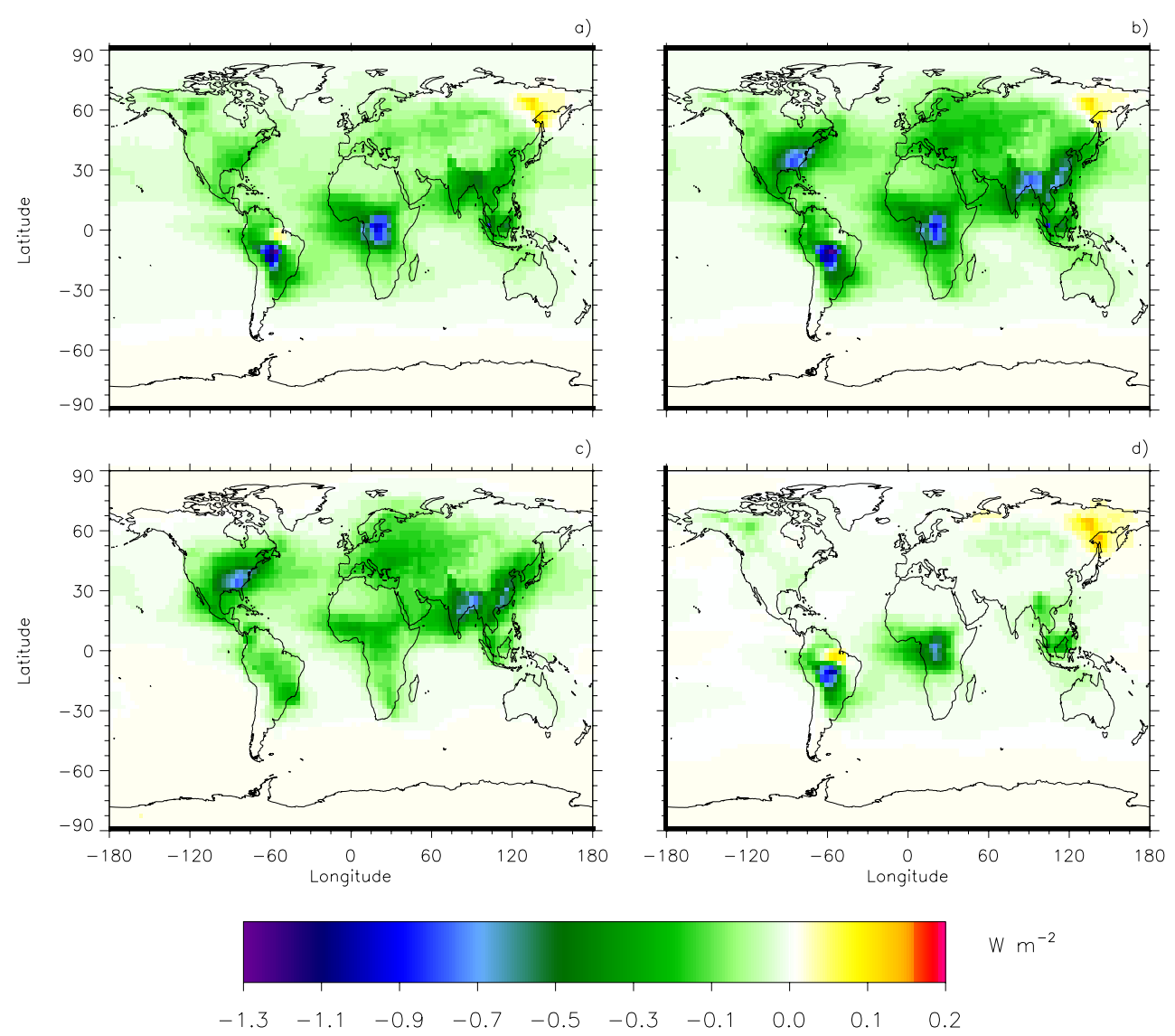

Fig. 3. The radiative forcing (RF) due to SOA increases between pre-industrial times and the present. Panel (a): SOA is allowed to partition to POA from all sources (calculated from Pind_nosul vs. Pres_nosul). Panel (b): same as panel (a), except partitioning to ASLA is allowed (Pind_sul vs. Pres_sul). Panel (c) shows the forcing excluding the effects of present day biomass burning (RF is calculated from Pind_sul vs. Pres_BBpind). Panel (d): RF is calculated from Pind_sul vs. Pind_BBpres, i.e. the RF is from the increase in SOA due to biomass burning POA and ASLA.

isoprene is being oxidised closer to the source, and therfore that more of the isoprene can lead to SOA formation before being washed out. We believe that the development of global SOA models has reached the stage where a detailed model inter-comparison would be very useful in determining the reasons for some of the differences between the models.

\subsection{The radiative forcing of changes in SOA burden}

The increase in SOA since 1750 resulted in a global annual average radiative forcing of $-0.058 \mathrm{~W} \mathrm{~m}^{-2}$ for run Pres_nosul, relative to Pind_nosul. In run Pres_sul, the forcing was $-0.086 \mathrm{~W} \mathrm{~m}^{-2}$, or about twice the the forcing due only to the increase in POA emitted by fossil fuel burning, $\left(-0.04 \mathrm{~W} \mathrm{~m}^{-2}\right)$ which was calculated with this model in a previous experiment (Schulz et al., 2006). Both forcing estimates modelled here are larger than the best estimate from the IPCC AR4 of the radiative forcing for POA (Forster et al., 2007), which was $-0.05[ \pm 0.05] \mathrm{W} \mathrm{m}^{-2}$. Table 3 shows that the increase in SOA due to industrial and fuel burning emis-
Table 6. The radiative forcing as a result of SOA increases since pre-industrial times, for the different model runs.

\begin{tabular}{lc}
\hline Run & $\mathrm{RF}\left(\mathrm{W} \mathrm{m}^{-2}\right)$ \\
\hline Pind_sul/Pres_sul & -0.086 \\
Pind_nosul/Pres_nosul & -0.058 \\
Pind_BBpres/Pind_sul & -0.021 \\
Pres_BBpind/Pind_sul & -0.056 \\
\hline
\end{tabular}

sions was about twice as large as that due to emissions of POA and sulphur from biomass burning; the radiative forcing caused by the SOA associated with the biomass burning emissions on the other hand (see Table 6), was only a little more than a third of that of the SOA associated with the industrial/fuel burning emissions $\left(-0.021 \mathrm{~W} \mathrm{~m}^{-2}\right.$ and $-0.056 \mathrm{~W} \mathrm{~m}^{-2}$, respectively).

The distribution of the radiative forcing caused by the SOA increases is shown in Fig. 3. Generally, the radiative forcing 
is strong over areas with large emissions of SOA precursors or POA, and weak over remote ocean areas and at high latitudes. Decreases in the magnitude of the radiative forcing are seen in areas where the emissions given in the present day inventory of POA from biomass burning are lower than those from the pre-industrial inventory, reducing the aerosol phase fraction of the semi-volatile organic species, as in Fig. 1.

Figure 3, panel A, shows the radiative forcing when SOA was not allowed to partition to ASLA. The strongest forcing is seen in the tropics, especially over South America and Africa where biomass burning emissions are large, but also over the ocean down wind of these areas, and over South East Asia. These forcings were enhanced when partitioning to ASLA was allowed (panel B), particularly over South East Asia. Additionally, the radiative forcings shown in panel B for the east coast of North America and over Europe are much stronger.

Panel C and D show the forcing calculated from runs Pres_BBpind and Pind_BBpres respectively. The radiative forcing resulting from the increased SOA due to industrial emissions occurred mainly over the industrial areas, while the forcing due to SOA partitioning to the increased levels of biomass burning POA is mainly evident over Southern Africa, Indonesia and South America, as expected, considering the distribution of SOA increases shown in Fig. 1. It should be noted again, that the radiative forcing calculated here is the direct radiative forcing, and that the model does not account for indirect effects such as the influence of aerosol on cloud cover.

\section{Discussion}

The production of SOA was found to have increased by approximately $19 \mathrm{Tg} \mathrm{yr}^{-1}$, since the pre-industrial period while the burden increased by $0.17 \mathrm{Tg}$, or about $51 \%$. When semivolatile organic species were also allowed to partition to ASLA, the production of SOA increased by $26 \mathrm{Tg} \mathrm{yr}^{-1}$, and the burden increased by $0.26 \mathrm{Tg}$, or $59 \%$. The major part of this change was due to increases in industrial emissions. The fact that the difference in SOA burden between Pres_sul and Pres_nosul is a large fraction of the difference in burden between Pres_sul and Pind_sul suggests that the mass of aerosol available for partitioning may be the most significant cause of the increase in SOA. Most of the mid to upper tropospheric SOA increase over the tropics appears not to be a result of increases in biomass burning emissions of POA or sulphur, rather due to industrial or fuel burning emissions.

The results also suggest that although the global burden of SOA has increased since pre-industrial times, the concentrations of SOA in the upper troposphere have decreased. This is due to changes in the altitudes and locations at which oxidation and partitioning of SOA species occur, which in turn affects the removal of the organic species from the atmosphere.
The radiative forcing resulting from SOA is $-0.06 \mathrm{Wm}^{-2}$ for Pres_nosul compared to Pind_nosul and $-0.09 \mathrm{Wm}^{-2}$, for Pres_sul, compared to Pind_sul. The radiative forcing modelled here is likely to be slightly weaker than the actual radiative forcing, due to the importance of the total OA burden for SOA partitioning, and the fact that in industrialised regions the model tends to underestimate the concentrations of OA (Hoyle et al., 2007).

Observations show a large fraction of OA to be secondary in origin (Crosier et al., 2007; Gelencser et al., 2007), and there are indications that anthropogenic VOC, or processing by anthropogenically influenced air masses, could be more important for SOA formation than the current state-ofthe-art SOA models predict (Volkamer et al., 2006; Crosier et al., 2007). Therefore, further characterisation of the anthropogenic effect on SOA formation is necessary to improve model results near industrialised areas.

If the work of Lelieveld et al. (2008) is confirmed, the development of a parameterisation for the recycling of $\mathrm{OH}$ during isoprene oxidation would be a substantial improvement to the chemistry leading to SOA formation. Such a mechanism would lead to higher SOA yields in areas with significant isoprene emissions, and may lead to a better match between modelled and measured OA values.

A further factor that may help improve the modelled mass of SOA, is the measurement of SOA yields in the laboratory, at an atmospherically relevant range of temperatures. This would reduce the reliance on the extrapolation of partitioning coefficients from a single temperature, using a generalised enthalpy of vaporisation.

The inclusion of ASLA as mass to which SOA can partition caused large increases in the amount of SOA in and near large industrial agglomerations. Regulations which lead to further reductions in emissions of sulphur may therefore lead to lower burdens of organic aerosol in, and down-wind of these areas. In order to model the effects of such reductions, however, the representation of sulphate aerosol and its interaction with organics in large scale models needs to be improved. Water uptake, as well as deliquescence and efflorescence of ammonium sulphate needs to be accounted for, as both these factors influence the uptake of semi-volatile organic species. Irreversible partitioning due to aerosol phase reactions also needs to be explicitly accounted for. These improvements will be a focus of future work with this model.

Acknowledgements. The authors would like to thank Ulrich Krieger of the Institute for Atmospheric and Climate Science, ETH Zurich, for advice on this manuscript from a laboratory perspective. This work was carried out with funding from the projects BACCI (Biosphere-Aerosol-Cloud-Climate Interactions) and EUCAARI (European Integrated project on Aerosol Cloud Climate and Air Quality Interactions). This study was also supported by the Norwegian Research Council.

Edited by: J. Seinfeld 


\section{References}

Berglen, T. F., Berntsen, T. K., Isaksen, I. S. A., and Sundet, J. K.: A global model of the coupled sulfur/oxidant chemistry in the troposphere: The sulfur cycle, J. Geophys. Res., 109, D19310, doi:10.1029/2003JD003948, 2004.

Berntsen, T. K. and Isaksen, I. S. A.: A global three-dimensional chemical transport model for the troposphere 1. Model description and CO and ozone results, J. Geophys. Res., 102, 2123921280, doi:10.1029/97JD01140, 1997.

Bond, T. C., Streets, D. G., Yarber, K. F., Nelson, S. M., Woo, J.-H., and Klimont, Z.: A technology-based global inventory of black and organic carbon emissions from combustion, J. Geophys. Res.-Atmos., 109, D14203, doi:10.1029/2003JD003697, 2004.

Brooks, S. D., DeMott, P. J., and Kreidenweis, S. M.: Water uptake by particles containing humic materials and mixtures of humic materials with ammonium sulfate, Atmos. Environ., 38, 18591868, 2004.

Chung, S. H. and Seinfeld, J. H.: Global distribution and climate forcing of carbonaceous aerosols, J. Geophys. Res.-Atmos., 107, doi:10.1029/2001JD001397, 2002.

Crosier, J., Allan, J. D., Coe, H., Bower, K. N., Formenti, P., and Williams, P. I.: Chemical composition of summertime aerosol in the Po Valley (Italy), northern Adriatic and Black Sea, Quart. J. Royal Meteorol. Soc., 133, 61-75, doi:10.1002/qj.88, 2007.

Dentener, F., Kinne, S., Bond, T., Boucher, O., Cofala, J., Generoso, S., Ginoux, P., Gong, S., Hoelzemann, J. J., Ito, A., Marelli, L., Penner, J. E., Putaud, J.-P., Textor, C., Schulz, M., van der Werf, G. R., and Wilson, J.: Emissions of primary aerosol and precursor gases in the years 2000 and 1750 prescribed data-sets for AeroCom, Atmos. Chem. Phys., 6, 4321-4344, 2006.

Dibb, J., Talbot, R., Klemm, K., Gregory, G., Singh, H., Bradshaw, J., and Sandholm, S.: Asian influence over the western North Pacific during the fall season: Inferences from lead 210, soluble ionic species and ozone, J. Geophys. Res.-Atmos., 101, 17791792, 1996.

Forster, P., Ramaswamy, V., Artaxo, P., Berntsen, T., Betts, R., Fahey, D., Haywood, J., Lean, J., Lowe, D., Myhre, G., Nganga, J., Prinn, R., Raga, G., Schulz, M., and R. Van Dorland: Climate Change 2007: The Physical Science Basis. Contribution of Working Group I to the Fourth Assessment Report of the Intergovernmental Panel on Climate Change, chap. 2, Changes in Atmospheric Constituents and in Radiative Forcing, Cambridge University Press, Cambridge, UK and New York, NY, USA, 129234, 2007.

Gelencser, A., May, B., Simpson, D., Sanchez-Ochoa, A., KasperGiebl, A., Puxbaum, H., Caseiro, A., Pio, C., and Legrand, M.: Source apportionment of PM2.5 organic aerosol over Europe: Primary/secondary, natural/anthropogenic, and fossil/biogenic origin, J. Geophys. Res.-Atmos., 112, doi:10.1029/ 2006JD008094, 2007.

Granier, C., Lamarque, J. F., Mieville, A., Muller, J. F., Olivier, J., Orlando, J., Peters, J., Petron, G., Tyndall, G., and Wallens, S.: POET, a database of surface emissions of ozone precursors, available online at: http://www.aero.jussieu.fr/projet/ACCENT/ POET.php, 2005.

Griffin, R. J., Cocker, D. R., Seinfeld, J. H., and Dabdub, D.: Estimate of global atmospheric organic aerosol from oxidation of biogenic hydrocarbons, Geophys. Res. Lett., 26, 2721-2724,
doi:10.1029/1999GL900476, 1999.

Guenther, A., Hewitt, C. N., Erickson, D., Fall, R., Geron, C., Graedel, T., Harley, P., Klinger, L., Lerdau, M., McKay, W. A., Pierce, T., Scholes, B., Steinbrecher, R., Tallamraju, R., Taylor, J., and Zimmerman, P.: A global model of natural volatile organic compound emissions, J. Geophys. Res., 100, 8873-8892, doi:10.1029/94JD02950, 1995.

Guenther, A., Karl, T., Harley, P., Wiedinmyer, C., Palmer, P. I., and Geron, C.: Estimates of global terrestrial isoprene emissions using MEGAN (Model of Emissions of Gases and Aerosols from Nature), Atmos. Chem. Phys., 6, 3181-3210, 2006, http://www.atmos-chem-phys.net/6/3181/2006/.

Heald, C. L., Henze, D. K., Horowitz, L. W., Feddema, J., Lamarque, J. F., Guenther, A., Hess, P. G., Vitt, F., Seinfeld, J. H., Goldstein, A. H., and Fung, I.: Predicted change in global secondary organic aerosol concentrations in response to future climate, emissions, and land use change, J. Geophys. Res. -Atmos., 113, doi:\{10.1029/2007JD009092\}, 2008.

Henze, D. K. and Seinfeld, J. H.: Global secondary organic aerosol from isoprene oxidation, Geophys. Res. Lett., 33, doi:10.1029/ 2006GL025976, 2006.

Henze, D. K., Seinfeld, J. H., Ng, N. L., Kroll, J. H., Fu, T. M., Jacob, D. J., and Heald, C. L.: Global modeling of secondary organic aerosol formation from aromatic hydrocarbons: high- vs. low-yield pathways, Atmos. Chem. Phys., 8, 2405-2420, 2008.

Hesstvedt, E., Hov, Ø., and Isaksen, I. S. A.: Quasi-Steady-State Approximations in Air-Pollution Modeling - Comparison of Two Numerical Schemes for Oxidant Prediction, Int. J. Chem. Kinet., 10, 971-994, 1978.

Hoyle, C. R., Berntsen, T., Myhre, G., and Isaksen, I. S. A.: Secondary organic aerosol in the global aerosol - chemical transport model Oslo CTM2, Atmos. Chem. Phys., 7, 5675-5694, 2007, http://www.atmos-chem-phys.net/7/5675/2007/.

Hoyle, C. R., Russo, M., Marecal, V., Chipperfield, M., et al.: Tropical deep convection and its impact on composition in global and mesoscale models: tracer transport, manuscript in preparation, 2009.

Huebert, B., Howell, S., Zhuang, L., Heath, J., Litchy, M., Wylie, D., Kreidler-Moss, J., Coppicus, S., and Pfeiffer, J.: Filter and impactor measurements of anions and cations during the First Aerosol Characterization Experiment (ACE 1), J. Geophys. Res.Atmos., 103, 16493-16509, 1998.

IPCC: Climate Change 2001: The Scientific Basis. Contribution of Working Group I to the Third Assessment Report of the Intergovernmental Panel on Climate Change, Cambridge University Press, Cambridge, UK and New York, NY, USA, 881 pp., 2001.

IPCC: Climate Change 2007: Synthesis Report. Contribution of Working Groups I II and III to the Fourth Assessment Report of the Intergovernmental Panel on Climate Change, IPCC, Geneva, Switzerland, 104 pp., 2007.

Iraci, L. and Tolbert, M.: Heterogeneous interaction of formaldehyde with cold sulfuric acid: Implications for the upper troposphere and lower stratosphere, J. Geophys. Res., 102, 16099 16107, 1997.

Jang, M., Czoschke, N., Lee, S., and Kamens, R.: Heterogeneous atmospheric aerosol production by acid-catalyzed particle-phase reactions, Science, 298, 814-817, 2002.

Kanakidou, M., Tsigaridis, K., Dentener, F. J., and Crutzen, P. J.: Human-activity-enhanced formation of organic aerosols by bio- 
genic hydrocarbon oxidation, J. Geophys. Res., 105, 9243-9254, doi:10.1029/1999JD901148, 2000.

Kanakidou, M., Seinfeld, J. H., Pandis, S. N., Barnes, I., Dentener, F. J., Facchini, M. C., van Dingenen, R., Ervens, B., Nenes, A., Nielsen, C. J., Swietlicki, E., Putaud, J. P., Balkanski, Y., Fuzzi, S., Horth, J., Moortgat, G. K., Winterhalter, R., Myhre, C. E. L., Tsigaridis, K., Vignati, E., Stephanou, E. G., and Wilson, J.: Organic aerosol and global climate modelling: a review, Atmos. Chem. Phys., 5, 1053-1123, 2005,

http://www.atmos-chem-phys.net/5/1053/2005/.

Kaufman, Y., Tanre, D., and Boucher, O.: A satellite view of aerosols in the climate system, Nature, 419, 215-223, doi:10.1038/nature01091, 2002.

Kleindienst, T., Edney, E., Lewandowski, M., Offenberg, J., and Jaoui, M.: Secondary organic carbon and aerosol yields from the irradiations of isoprene and alpha-pinene in the presence of $\mathrm{NO}_{\mathrm{x}}$ and $\mathrm{SO}_{2}$, Environ. Sci. Technol., 40, 3807-3812, doi:10.1021/ es052446r, 2006.

Kleindienst, T. E., Smith, D. F., Li, W., Edney, E. O., Driscoll, D. J., Speer, R. E., and Weathers, W. S.: Secondary organic aerosol formation from the oxidation of aromatic hydrocarbons in the presence of dry submicron ammonium sulphate aerosol, Atmos. Environ., 33, 3669-3681, 1999.

Kline, J., Huebert, B., Howell, S., Blomquist, B., Zhuang, J., Bertram, T., and Carrillo, J.: Aerosol composition and size versus altitude measured from the C-130 during ACE-Asia, J. Geophys. Res., 109, D19S08, doi:\{10.1029/2004JD004540\}, 2004.

Lathière, J., Hauglustaine, D. A., De Noblet-Ducoudré, N., Krinner, G., and Folberth, G. A.: Past and future changes in biogenic volatile organic compound emissions simulated with a global dynamic vegetation model, Geophys. Res. Lett., 32, 20818, doi:10.1029/2005GL024164, 2005.

Lathière, J., Hauglustaine, D. A., Friend, A. D., de NobletDucoudré, N., Viovy, N., and Folberth, G. A.: Impact of climate variability and land use changes on global biogenic volatile organic compound emissions, Atmos. Chem. Phys., 6, 2129-2146, 2006, http://www.atmos-chem-phys.net/6/2129/2006/.

Lelieveld, J., Butler, T. M., Crowley, J. N., Dillon, T. J., Fischer, H., Ganzeveld, L., Harder, H., Lawrence, M. G., Martinez, M., Taraborrelli, D., and Williams, J.: Atmospheric oxidation capacity sustained by a tropical forest, Nature, 452, 737-740, doi: 10.1038/nature06870, 2008.

Liao, H. and Seinfeld, J. H.: Global impacts of gas-phase chemistryaerosol interactions on direct radiative forcing by anthropogenic aerosols and ozone, J. Geophys. Res.-Atmos., 110, D18208, doi: 10.1029/2005JD005907, 2005.

Lukács, H., Gelencsér, A., Hoffer, A., Kiss, G., Horváth, K., and Hartyáni, Z.: Quantative assessment of organosulfates in sizesegregated rural fine aerosol, Atmos. Chem. Phys., 9, 231-238, 2009, http://www.atmos-chem-phys.net/9/231/2009/.

Martin, S., Hung, H., Park, R., Jacob, D., Spurr, R., Chance, K., and Chin, M.: Effects of the physical state of tropospheric ammonium-sulfate-nitrate particles on global aerosol direct radiative forcing, Atmos. Chem. Phys., 4, 183-214, 2004.

Meyer, N., Duplissy, J., Gysel, M., Metzger, A., Dommen, J., Weingartner, E., Alfarra, M. R., Prevot, A. S. H., Fletcher, C., Good, N., McFiggans, G., Jonsson, A. M., Hallquist, M., Baltensberger, U., and Ristovski, Z. D.: Analysis of the hygroscopic and volatile properties of ammonium sulphate seeded and unseeded SOA par- ticles, Atmos. Chem. Phys., 9, 721-723, 2009, http://www.atmos-chem-phys.net/9/721/2009/.

Muller, J. F., Stavrakou, T., Wallens, S., De Smedt, I., Van Roozendael, M., Potosnak, M. J., Rinne, J., Munger, B., Goldstein, A., and Guenther, A. B.: Global isoprene emissions estimated using MEGAN, ECMWF analyses and a detailed canopy environment model, Atmos. Chem. Phys., 8, 1329-1341, 2008.

Myhre, G., Jonson, J. E., Bartnicki, J., Stordal, F., and Shine, K. P.: Role of spatial and temporal variations in the computation of radiative forcing due to sulphate aerosols: A regional study, Q. J. Roy. Meteor. Soc., 128, 973-989, 2002.

Myhre, G., Bellouin, N., Berglen, T. F., Berntsen, T. K., Boucher, O., Grini, A., Isaksen, I. S. A., Johnsrud, M., Mishchenko, M. I., Stordal, F., and Tanré, D.: Comparison of the radiative properties and direct radiative effect of aerosols from a global aerosol model and remote sensing data over ocean, Tellus, 59B, 115-129, doi: 10.1111/j.1600-0889.2006.00226.x, 2007.

Odum, J. R., Hoffmann, T., Bowman, F., Collins, D., Flagan, R. C., and Seinfeld, J. H.: Gas/Particle Partitioning and Secondary Organic Aerosol Yields, Environ. Sci. Technol., 30, 2580-2585, 1996.

Peng, C., Chan, M. N., and Chan, C. K.: The hygroscopic properties of dicarboxylic and multifunctional acids: Measurements and UNIFAC predictions, Environ. Sci. Technol., 35, 4495-4501, 2001.

Prenni, A. J., DeMott, P. J., and Kreidenweis, S. M.: Water uptake of internally mixed particles containing ammonium sulfate and dicarboxylic acids, Atmos. Environ., 37, 4243-4251, 2003.

Schulz, M., Textor, C., Kinne, S., Balkanski, Y., Bauer, S., Berntsen, T., Berglen, T., Boucher, O., Dentener, F., Guibert, S., Isaksen, I. S. A., Iversen, T., Koch, D., Kirkevåg, A., Liu, X., Montanaro, V., Myhre, G., Penner, J. E., Pitari, G., Reddy, S., Seland, Ø., Stier, P., and Takemura, T.: Radiative forcing by aerosols as derived from the AeroCom present-day and pre-industrial simulations, Atmos. Chem. Phys., 6, 5225-5246, 2006,

http://www.atmos-chem-phys.net/6/5225/2006/.

Stamnes, K., Tsay, S.-C., Jayaweera, K., and Wiscombe, W.: Numerically stable algorithm for discrete-ordinate-method radiative transfer in multiple scattering and emitting layered media, Appl. Opt., 27, 2502-2509, 1988.

Surratt, J. D., Kroll, J. H., Kleindienst, T. E., Edney, E. O., Claeys, M., Sorooshian, A., Ng, N. L., Offenberg, J. H., Lewandowski, M., Jaoui, M., Flagan, R. C., and Seinfeld, J. H.: Evidence for organosulfates in secondary organic aerosol, Environ. Sci. Technol., 41, 517-527, doi:\{10.1021/es062081q\}, 2007.

Svenningsson, B., Rissler, J., Swietlicki, E., Mircea, M., Bilde, M., Facchini, M. C., Decesari, S., Fuzzi, S., Zhou, J., Monster, J., and Rosenorn, T.: Hygroscopic growth and critical supersaturations for mixed aerosol particles of inorganic and organic compounds of atmospheric relevance, Atmos. Chem. Phys., 6, 1937-1952, 2006, http://www.atmos-chem-phys.net/6/1937/2006/.

Tsigaridis, K. and Kanakidou, M.: Global modelling of secondary organic aerosol in the troposphere: A sensitivity analysis, Atmos. Chem. Phys., 3, 2879-2929, 2003, http://www.atmos-chem-phys.net/3/2879/2003/.

Tsigaridis, K. and Kanakidou, M.: Secondary organic aerosol importance in the future atmosphere, ATMOSPHERIC ENVIRONMENT, 41, 4682-4692, doi:\{10.1016/j.atmosenv.2007.03.045\}, 
2007.

Tsigaridis, K., Lathière, J., Kanakidou, M., and Hauglustaine, D. A.: Naturally driven variability in the global secondary organic aerosol over a decade, Atmos. Chem. Phys., 5, 1891-1904, 2005, http://www.atmos-chem-phys.net/5/1891/2005/.

Tsigaridis, K., Krol, M., Dentener, F. J., Balkanski, Y., Lathière, J., Metzger, S., Hauglustaine, D. A., and Kanakidou, M.: Change in global aerosol composition since preindustrial times, Atmos. Chem. Phys., 6, 5143-5162, 2006,

http://www.atmos-chem-phys.net/6/5143/2006/. van der Werf, G. R., Randerson, J. T., Giglio, L., Collatz, G. J., Kasibhatla, P. S., and Arellano, Jr., A. F.: Interannual variability in global biomass burning emissions from 1997 to 2004, Atmos. Chem. Phys., 6, 3423-3441, 2006, http://www.atmos-chem-phys.net/6/3423/2006/.

Volkamer, R., Jimenez, J. L., San Martini, F., Dzepina, K., Zhang, Q., Salcedo, D., Molina, L. T., Worsnop, D. R., and Molina, M. J.: Secondary organic aerosol formation from anthropogenic air pollution: Rapid and higher than expected, Geophys. Res. Lett., 33, L17811, doi:10.1029/2006GL026899, 2006. 